\title{
Comparative Theoretical Analysis of Biomass and Energy Potentials of Usable Maize and Wheat Stalk Wastes: Example of Sakarya Province
}

\author{
Muhammed Taşova ${ }^{1, a, *}$, İsmail Naneli ${ }^{2, b}$ \\ ${ }^{1}$ Department of Biosystem Engineering, Faculty of Agriculture, Tokat Gaziosmanpaşa University, 60250 Tokat, Turkey \\ ${ }^{2}$ Field Crops Department, Agricultural Faculty, Sakarya University of Applied Sciences, 54700 Sakarya, Turkey
}

*Corresponding author

A R T I C L E IN F O A B S T R A C T

Research Article

With the increase in the population in the world and in our country, the energy requirement related to consumer demands is constantly increasing. In our country, although wind, sun, etc. energy sources are used in energy production, fuels of fossil origin (coal, natural gas, oil etc.) are used more in energy production. Renewable energy sources, which are alternative due to the decrease in fossil

Received : 03/08/2020

Accepted : 04/09/2020 fuel reserves, negative environmental effects and inability to meet the energy needs in the future, come to the fore. In this study, Turkey Statistical Institute (TUIK) according to the 2015-2019 year data, Sakarya at the central and districts in cultivation areas for cultivated of using the amounts of maize and wheat product (da) average waste, dry matter, and volatile dry matter, methane and energy their potential has been determined. As a result of the calculations, it has been determined that the maize sap waste amount has the highest 25695.68 tons of waste and $201197.15 \mathrm{MJ}$ energy

Keywords: potential in Adapazar1 district in 2017. Among the wheat stalk wastes, in 2017, Geyve district had

Maize and wheat wastes the highest 269.95 tons of waste and $2113.72 \mathrm{MJ}$ energy respectively.

Methane and energy potential Sakarya

Renewable energy

Fossil

muhammed.tasova@gop.edu.tr

iD https://orcid.org/0000-0001-5025-0807

b@ismailnaneli@subu.edu.tr

https://orcid.org/0000-0002-6377-5263

(c) () () (9) This work is licensed under Creative Commons Attribution 4.0 International License

\section{Introduction}

Amounts of use are constantly decreasing, as the reserves of fossil energy sources decrease and cause irreversible environmental problems (Afazeli et al., 2014; Zareei, 2018; Tasova and Naneli, 2019). Using nonrenewable resources in energy production increases greenhouse gas emission rates, but also increases global warming and climate change (Momayez et al., 2018). For this reason, the use and technologies of more environmentally friendly renewable energy sources are developing rapidly. One of the renewable energy sources is biogas. Biogas, especially used in rural areas and agroindustrial areas, is also known as green energy. It is a gas group that occurs as a result of microbial decay of organic substances in the oxygen-free environment. The biogas produced varies depending on the parameters and intensities examined in the facilities.

It contains an average of $35-75 \% \mathrm{CH}_{4}, 25-65 \% \mathrm{CO}_{2}, 1-$ $5 \% \mathrm{H}_{2}$ and little amounts of ammonia, water vapor and hydrogen sulfide (Yentekakis and Goula, 2017; Ullah
Khan et al., 2017; Momayez et al., 2018). Wastes, which are the raw materials of biogas; besides water, soil, and air pollution, affects human health negatively. In this context, it is necessary to manage the waste. One of these management forms is energy production within the scope of sustainable development. Energy production within the scope of sustainable development is the process of converting the fermentable biomass involved in the process of anaerobic decomposition into biogas, where methane and carbon dioxide are dense. The gas obtained as a result of the specified process is converted into electrical energy by burning it in engines as well as indirect heating processes. Also, it is processed in cogeneration units and its use as biomethane instead of natural gas increases both quality and functionality (Da Costa Gomez, 2013; San Minguela and Godoy, 2015; Ruiz et al., 2018). Organic origin waste is performed both with sustainable use of energy form conversion is inhibited greatly damages the environment (Figure 1). 


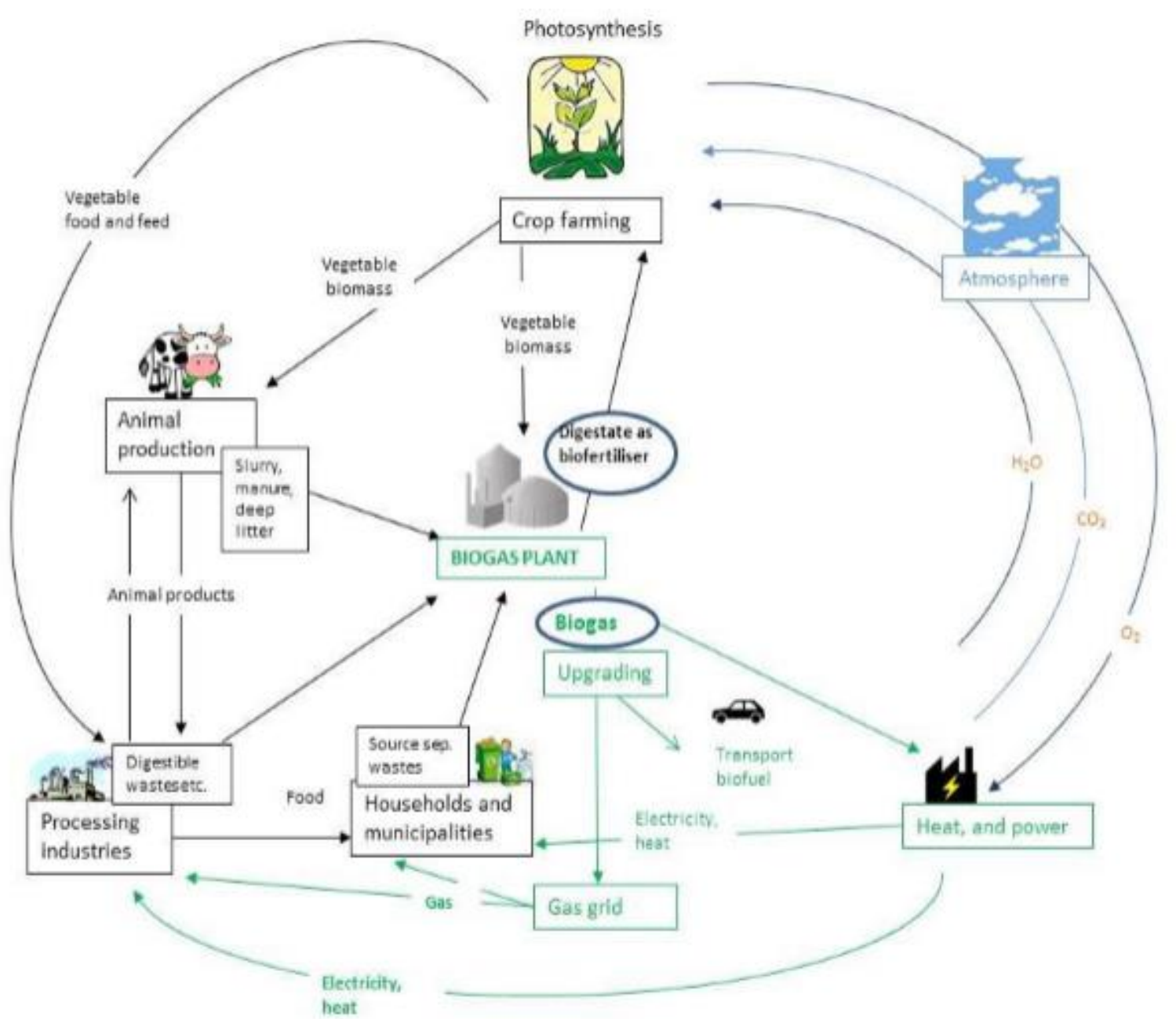

Figure 1. Conversion and use of organic wastes into energy

Biomass formed by photosynthesis is consumed by animals (Figure 1). The remaining herbal wastes, after the digestion in the biogas plant, are transformed into secondary energy as heat and electrical energy by passing through the different systems. Bionic fertilizer, which remains after the use of animal waste in biogas production, is also given to plants as a nutrient. This system continues as a closed-loop. As with all renewable energy sources, investment costs are high in the establishment of biogas facilities. For this reason, it may not be appropriate to establish the facility in any location with biological waste. Feasibility studies are carried out before the establishment of biogas facilities. At the beginning of these studies, there is an obligation to determine a waste and energy potential in the place where the facility is planned to be established. In this context, studies are carried out in the literature on determining the potential state. Khalil et al. (2019), They determined the biogas potential that can be obtained from the wastes of animal origin from Indonesia. Hazer and Ammenberg (2019), They determined the biomass, biogas, and energy potential values that can be obtained from some agricultural waste in the city of Hazaribagh, Bangladesh. Howell et al. (2019), They researched the biogas potential that can be obtained from the domestic waste coming to the municipal waste facility with the prediction method. Ramos-Suarez et al. (2019), They determined the biogas and energy potentials that can be obtained from animal waste in the Canary Islands. Besides, they stated that in this study, 495.622 tons of waste is produced annually. In this study, Turkey/Sakarya province center and districts have grown in the years 2015-2019 that the usable stalk waste amounts (ton/year), dry matter (ton/year), volatile dry matter $\left(\mathrm{m}^{3} /\right.$ year) and methane gas energy potentials (MJ/year) in maize and wheat lands were investigated.

\section{Material and Method}

\section{The Research Material}

Sakarya Province of maize and wheat stalk biomass and waste to determine the energy potential of Turkey Statistical Institute (TSI)' s cultivation amounts (da) between the years 2015 to 2019 taken from the official site was used.

\section{Calculation Methods}

Between 2015-2019, sowing amounts (da) in maize and wheat fields grown based on Sakarya center and districts are given in Table 1. Average waste amounts were determined by using maize and wheat cultivation values given in Table 1 by years. While determining these values, the harvested proportions of products were used. Maize is calculated with $60 \%$ and wheat with $15 \%$ (Öztürk and Başçetinçelik, 2006). Dry matter, volatile dry matter and total methane potential values that can be obtained from wastes according to Sharma et al. (1988) the methods used. Literature data were used to determine the volatile dry 
matter value. Methane gas ( $\mathrm{m}^{3} /$ year) and energy $(\mathrm{MJ} / \mathrm{year})$ potentials of maize and wheat wastes that can be obtained were determined according to the methods used in Aybek et al. (2015)' s studies.

The parameters and formulas used for maize are given as an example in equations 1-5.

$$
\mathrm{AP}=((\mathrm{EA} \times 527 \times 0.6) / 1000)
$$

Here; AP, waste potential of maize product (ton / year); EA, wheat planting area (da).

$$
\mathrm{KM}=((\mathrm{AP} \times 88) / 100)
$$

Here; KM, Available dry matter potential (tons/year).

$$
\mathrm{UKM}=((\mathrm{AP} \times 87) / 100)
$$

Here; UKM, Dry matter potential (tons/year).

$$
\text { ÖMO }=(\mathrm{UKM} \times 0.25)
$$

Here; ÖMO, Specific methane ratio $\left(\mathrm{CH}_{4} \mathrm{~kg}\right)$.

$$
\mathrm{ME}=(\mathrm{ÖMO} \times 36)
$$
(MJ).

Here; ME, the Energy value of available methane gas

In the studies reviewed, the coefficients of the stalk waste that can be used for wheat and other products were specified in detail (Sharma et al., 1988; Öztürk and Başçetinçelik, 2006; Aybek et al., 2015).

\section{Results and Discussion}

The Waste Amount, Dry Matter, Volatile Dry Matter

The potential of waste, dry matter and volatile dry matter calculated from the maize field grown in the centers and districts of Sakarya province and the areas are given in Table 1.

According to Table 1, the highest collectible waste material potential for maize products in Sakarya center and districts between 2015 and 2019 was determined as 25695.68 tons/year in 2017 in Adapazar1 district. According to the table, there is no data for Pamukova district. This situation is thought to be because no data record of maize cultivation was created between 2015 and 2019 , or that the amount grown between the specified years was very low.

The lowest maize waste potential among the years specified outside of Pamukova district was determined in Sapanca district with 3.16 tons/year. It was observed that the same data was calculated in terms of the parameters specified in 2015, 2018 and 2019. In terms of dry matter and volatile dry matter parameter, it is the highest and the lowest potential Adapazarı and Pamukova respectively, the maximum values in 2017 in Adapazarı location were obtained. In Pamukova location, the minimum potential value was determined in all the years examined (Table 1). The findings of methane gas and energy potential that can be obtained from maize waste were given in Table 2.

According to Table 2, the methane gas and energy potentials that can be obtained from the available maize stalk wastes of Sakarya province between 2015-2019 have been determined. In line with the findings, the district with the highest methane gas and energy potential was Adapazar1 in 2017. The determined values were 5588.81 $\mathrm{m}^{3} /$ year and 201197.15 MJ/year, respectively.

Available waste potentials for wheat products grown in the specified years for Sakarya centers and districts are given in Table 3.

According to Table 3, the highest potential in terms of usable waste material of wheat grown in Sakarya center and districts between 2015 and 2019 was determined in Geyve district as 269.95 tons/year in 2017. There is no data for Kocaali and Sapanca districts (Table 3). This situation is thought to be caused by the fact that there is no data record on how much wheat is cultivated between 2015 and 2019 , or because the amount of cultivated area between the specified years is very low. There is no clear information about the data status of Kocaali and Sapanca districts. The lowest wheat waste potential among the specified years was determined as 0.22 tons/year in Arifiye district especially in 2019. The highest and lowest potentials in terms of dry matter and volatile dry matter parameters were found to be valid for the same location and years.

Between the years studied, the findings of methane gas and energy potentials that can be obtained from wheat wastes are given in Table 4.

According to Table 4, the methane gas and energy potentials that can be obtained from the collectible wheat stalk waste belonging to Sakarya between the years of 2015-2019 have been determined. In line with the findings, it was determined in 2017 that Geyve is the district with the highest methane gas and energy potentials. The determined values were $58.71 \mathrm{~m}^{3} /$ year and 2113.72 $\mathrm{MJ} /$ year, respectively.

Khalil et al. (2019), They identified the biogas potential of Indonesia that can be obtained from animal wastes. They stated that $9597.4 \mathrm{~mm}^{3}$ biogas per year from animal wastes and $1.7 \times 106 \mathrm{kWh} /$ year electrical energy can be produced from the obtained gas. Bao et al. (2019), They determined the waste potential that can be obtained from farm animals in 2013-2015 in some locations in China. In the study, they determined that there is an average of $414.90 \mathrm{Mt}$ dry matter potential per year from usable wet wastes. Gao et al. (2019), They determined the biogas potentials that can be obtained from the waste of olive, cotton, tuber, maize, wheat and paddy products grown in Henan city of China between 2009-2014. According to the findings, $42.24 \%$ of the biogas that can be obtained from wheat stalks, $34.50 \%$ from maize stalks, and the lowest rate can be obtained from tuberous products. In the study, it was stated that the biggest factors affecting these rates were the area in which it was grown and the yield amounts. Hasan and Ammenberg (2019), They reported that the amount of biogas that can be obtained daily from organic wastes in Hazaribagh city of Bangladesh is $6 \mathrm{mt}$. In line with the findings, biogas and energy potentials that can be obtained from organic wastes, the number of animals, the number of areas where plant products are grown, the yield of the crops in the field and the different biochemical structure of the wastes are considered as the most important factors. 
Table 1. Waste and volatile dry matter potentials of maize

\begin{tabular}{|c|c|c|c|c|c|}
\hline Locations & Year & $\begin{array}{c}\text { Cultivated area } \\
\text { (da) }\end{array}$ & $\begin{array}{c}\text { Waste amount } \\
\text { (tons/year) }\end{array}$ & $\begin{array}{l}\text { Dry matter } \\
\text { (tons/year) }\end{array}$ & $\begin{array}{c}\text { Volatile dry matter } \\
\left(\mathrm{m}^{3} / \text { year }\right)\end{array}$ \\
\hline \multirow{5}{*}{ Adapazarı } & 2015 & 66296 & 20962.80 & 18447.26 & 18237.63 \\
\hline & 2016 & 72260 & 22848.61 & 20106.78 & 19878.29 \\
\hline & 2017 & 81264 & 25695.68 & 22612.20 & 22355.24 \\
\hline & 2018 & 75262 & 23797.84 & 20942.10 & 20704.12 \\
\hline & 2019 & 63542 & 20091.98 & 17680.94 & 17480.02 \\
\hline \multirow{5}{*}{ Akyazı } & 2015 & 75857 & 23985.98 & 21107.67 & 20867.81 \\
\hline & 2016 & 68367 & 21617.65 & 19023.53 & 18807.35 \\
\hline & 2017 & 61419 & 19420.69 & 17090.21 & 16896.00 \\
\hline & 2018 & 55930 & 17685.07 & 15562.86 & 15386.01 \\
\hline & 2019 & 64948 & 20536.56 & 18072.17 & 17866.81 \\
\hline \multirow{5}{*}{ Arifiye } & 2015 & 11380 & 3598.36 & 3166.55 & 3130.57 \\
\hline & 2016 & 11276 & 3565.47 & 3137.61 & 3101.96 \\
\hline & 2017 & 10541 & 3333.06 & 2933.10 & 2899.77 \\
\hline & 2018 & 9491 & 3001.05 & 2640.93 & 2610.92 \\
\hline & 2019 & 10591 & 3348.87 & 2947.01 & 2913.52 \\
\hline \multirow{5}{*}{ Erenler } & 2015 & 36552 & 11557.74 & 10170.81 & 10055.24 \\
\hline & 2016 & 34524 & 10916.49 & 9606.51 & 9497.35 \\
\hline & 2017 & 35955 & 11368.97 & 10004.69 & 9891.00 \\
\hline & 2018 & 32299 & 10212.94 & 8987.39 & 8885.26 \\
\hline & 2019 & 33217 & 10503.22 & 9242.83 & 9137.80 \\
\hline \multirow{5}{*}{ Ferizli } & 2015 & 20931 & 6618.38 & 5824.18 & 5757.99 \\
\hline & 2016 & 22517 & 7119.88 & 6265.49 & 6194.29 \\
\hline & 2017 & 27600 & 8727.12 & 7679.87 & 7592.59 \\
\hline & 2018 & 25291 & 7997.01 & 7037.37 & 6957.40 \\
\hline & 2019 & 21800 & 6893.16 & 6065.98 & 5997.05 \\
\hline \multirow{5}{*}{ Geyve } & 2015 & 251 & 79.37 & 69.84 & 69.05 \\
\hline & 2016 & 270 & 85.37 & 75.13 & 74.28 \\
\hline & 2017 & 276 & 87.27 & 76.80 & 75.93 \\
\hline & 2018 & 233 & 73.67 & 64.83 & 64.10 \\
\hline & 2019 & 427 & 135.02 & 118.82 & 117.47 \\
\hline \multirow{5}{*}{ Hendek } & 2015 & 27629 & 8736.29 & 7687.94 & 7600.57 \\
\hline & 2016 & 29723 & 9398.41 & 8270.60 & 8176.62 \\
\hline & 2017 & 29440 & 9308.93 & 8191.86 & 8098.77 \\
\hline & 2018 & 26977 & 8530.13 & 7506.51 & 7421.21 \\
\hline & 2019 & 27897 & 8821.03 & 7762.51 & 7674.30 \\
\hline \multirow{5}{*}{ Karapürçek } & 2015 & 989 & 312.72 & 275.20 & 272.07 \\
\hline & 2016 & 833 & 263.39 & 231.79 & 229.15 \\
\hline & 2017 & 772 & 244.11 & 214.81 & 212.37 \\
\hline & 2018 & 698 & 220.71 & 194.22 & 192.02 \\
\hline & 2019 & 684 & 216.28 & 190.33 & 188.16 \\
\hline & 2015 & 17298 & 5469.63 & 4813.27 & 4758.58 \\
\hline & 2016 & 15580 & 4926.40 & 4335.23 & 4285.96 \\
\hline Karasu & 2017 & 15640 & 4945.37 & 4351.92 & 4302.47 \\
\hline & 2018 & 13657 & 4318.34 & 3800.14 & 3756.96 \\
\hline & 2019 & 12054 & 3811.47 & 3354.10 & 3315.98 \\
\hline & 2015 & 19908 & 6294.91 & 5539.52 & 5476.57 \\
\hline & 2016 & 13208 & 4176.37 & 3675.21 & 3633.44 \\
\hline Kaynarca & 2017 & 12492 & 3949.97 & 3475.97 & 3436.47 \\
\hline & 2018 & 11108 & 3512.35 & 3090.87 & 3055.74 \\
\hline & 2019 & 8336 & 2635.84 & 2319.54 & 2293.18 \\
\hline & 2015 & 940 & 297.23 & 261.56 & 258.59 \\
\hline & 2016 & 808 & 255.49 & 224.83 & 222.28 \\
\hline Kocaali & 2017 & 731 & 231.14 & 203.41 & 201.09 \\
\hline & 2018 & 637 & 201.42 & 177.25 & 175.23 \\
\hline & 2019 & 530 & 167.59 & 147.48 & 145.80 \\
\hline & 2015 & 10 & 3.16 & 2.78 & 2.75 \\
\hline & 2016 & 11 & 3.48 & 3.06 & 3.03 \\
\hline Sapanca & 2017 & 11 & 3.48 & 3.06 & 3.03 \\
\hline & 2018 & 10 & 3.16 & 2.78 & 2.75 \\
\hline & 2019 & 10 & 3.16 & 2.78 & 2.75 \\
\hline & 2015 & 6817 & 2155.54 & 1896.87 & 1875.32 \\
\hline & 2016 & 5939 & 1877.91 & 1652.56 & 1633.78 \\
\hline Serdivan & 2017 & 11100 & 3509.82 & 3088.64 & 3053.54 \\
\hline & 2018 & 9654 & 3052.59 & 2686.28 & 2655.76 \\
\hline & 2019 & 8173 & 2584.30 & 2274.19 & 2248.34 \\
\hline & 2015 & 53015 & 16763.34 & 14751.74 & 14584.11 \\
\hline & 2016 & 49957 & 15796.40 & 13900.83 & 13742.87 \\
\hline Söğ̈̈tlü & 2017 & 56189 & 17766.96 & 15634.93 & 15457.26 \\
\hline & 2018 & 51294 & 16219.16 & 14272.86 & 14110.67 \\
\hline & 2019 & 49132 & 15535.54 & 13671.27 & 13515.92 \\
\hline & 2015 & 29 & 9.17 & 8.07 & 7.98 \\
\hline & 2016 & 26 & 8.22 & 7.23 & 7.15 \\
\hline Taraklı & 2017 & 28 & 8.85 & 7.79 & 7.70 \\
\hline & 2018 & 30 & 9.49 & 8.35 & 8.25 \\
\hline & 2019 & 38 & 12.02 & 10.57 & 10.45 \\
\hline Pamukova & & 0 & 0 & 0 & 0 \\
\hline
\end{tabular}


Table 2. Methane gas and energy potentials of maize

\begin{tabular}{|c|c|c|c|}
\hline Locations & Year & Methane gas $\left(\mathrm{m}^{3} /\right.$ year $)$ & Energy value (MJ/year) \\
\hline \multirow{5}{*}{ Adapazarı } & 2015 & 4559.41 & 164138.69 \\
\hline & 2016 & 4969.57 & 178904.63 \\
\hline & 2017 & 5588.81 & 201197.15 \\
\hline & 2018 & 5176.03 & 186337.12 \\
\hline & 2019 & 4370.01 & 157320.21 \\
\hline \multirow{5}{*}{ Akyazı } & 2015 & 5216.95 & 187810.25 \\
\hline & 2016 & 4701.84 & 169266.16 \\
\hline & 2017 & 4224.00 & 152063.99 \\
\hline & 2018 & 3846.50 & 138474.07 \\
\hline & 2019 & 4466.70 & 160801.25 \\
\hline \multirow{5}{*}{ Arifiye } & 2015 & 782.64 & 28175.13 \\
\hline & 2016 & 775.49 & 27917.64 \\
\hline & 2017 & 724.94 & 26097.89 \\
\hline & 2018 & 652.73 & 23498.25 \\
\hline & 2019 & 728.38 & 26221.68 \\
\hline \multirow{5}{*}{ Erenler } & 2015 & 2513.81 & 90497.12 \\
\hline & 2016 & 2374.34 & 85476.11 \\
\hline & 2017 & 2472.75 & 89019.04 \\
\hline & 2018 & 2221.32 & 79967.35 \\
\hline & 2019 & 2284.45 & 82240.18 \\
\hline \multirow{5}{*}{ Ferizli } & 2015 & 1439.50 & 51821.93 \\
\hline & 2016 & 1548.57 & 55748.62 \\
\hline & 2017 & 1898.15 & 68333.35 \\
\hline & 2018 & 1739.35 & 62616.62 \\
\hline & 2019 & 1499.26 & 53973.44 \\
\hline \multirow{5}{*}{ Geyve } & 2015 & 17.26 & 621.44 \\
\hline & 2016 & 18.57 & 668.48 \\
\hline & 2017 & 18.98 & 683.33 \\
\hline & 2018 & 16.02 & 576.87 \\
\hline & 2019 & 29.37 & 1057.19 \\
\hline \multirow{5}{*}{ Hendek } & 2015 & 1900.14 & 68405.15 \\
\hline & 2016 & 2044.15 & 73589.57 \\
\hline & 2017 & 2024.69 & 72888.91 \\
\hline & 2018 & 1855.30 & 66790.90 \\
\hline & 2019 & 1918.57 & 69068.68 \\
\hline \multirow{5}{*}{ Karapürçek } & 2015 & 68.02 & 2448.61 \\
\hline & 2016 & 57.29 & 2062.38 \\
\hline & 2017 & 53.09 & 1911.35 \\
\hline & 2018 & 48.00 & 1728.14 \\
\hline & 2019 & 47.04 & 1693.48 \\
\hline \multirow{5}{*}{ Karasu } & 2015 & 1189.64 & 42827.18 \\
\hline & 2016 & 1071.49 & 38573.68 \\
\hline & 2017 & 1075.62 & 38722.23 \\
\hline & 2018 & 939.24 & 33812.63 \\
\hline & 2019 & 829.00 & 29843.85 \\
\hline & 2015 & 1369.14 & 49289.14 \\
\hline & 2016 & 908.36 & 32700.97 \\
\hline Kaynarca & 2017 & 859.12 & 30928.27 \\
\hline & 2018 & 763.94 & 27501.70 \\
\hline & 2019 & 573.30 & 20638.65 \\
\hline & 2015 & 64.65 & 2327.30 \\
\hline & 2016 & 55.57 & 2000.48 \\
\hline Kocaali & 2017 & 50.27 & 1809.84 \\
\hline & 2018 & 43.81 & 1577.11 \\
\hline & 2019 & 36.45 & 1312.20 \\
\hline & 2015 & 0.69 & 24.76 \\
\hline & 2016 & 0.76 & 27.23 \\
\hline Sapanca & 2017 & 0.76 & 27.23 \\
\hline & 2018 & 0.69 & 24.76 \\
\hline & 2019 & 0.69 & 24.76 \\
\hline & 2015 & 468.83 & 16877.84 \\
\hline & 2016 & 408.45 & 14704.05 \\
\hline Serdivan & 2017 & 763.39 & 27481.89 \\
\hline & 2018 & 663.94 & 23901.82 \\
\hline & 2019 & 562.09 & 20235.09 \\
\hline & 2015 & 3646.03 & 131256.98 \\
\hline & 2016 & 3435.72 & 123685.84 \\
\hline Söğ̈̈tlü & 2017 & 3864.31 & 139115.31 \\
\hline & 2018 & 3527.67 & 126996.04 \\
\hline & 2019 & 3378.98 & 121643.27 \\
\hline & 2015 & 1.99 & 71.80 \\
\hline & 2016 & 1.79 & 64.37 \\
\hline Taraklı & 2017 & 1.93 & 69.32 \\
\hline & 2018 & 2.06 & 74.28 \\
\hline & 2019 & 2.61 & 94.08 \\
\hline Pamukova & & 0 & 0 \\
\hline
\end{tabular}


Table 3. Waste and volatile dry matter potentials of wheat

\begin{tabular}{|c|c|c|c|c|c|}
\hline Locations & Year & $\begin{array}{c}\text { Cultivated area } \\
\text { (da) }\end{array}$ & $\begin{array}{c}\text { Waste amount } \\
\text { (ton/year) }\end{array}$ & $\begin{array}{c}\text { Dry matter } \\
\text { (ton/y1l) }\end{array}$ & $\begin{array}{c}\begin{array}{c}\text { Volatile dry matter } \\
\left(\mathrm{m}^{3} / \mathrm{y} 1 \mathrm{l}\right)\end{array} \\
\end{array}$ \\
\hline \multirow{5}{*}{ Adapazarı } & 2015 & 20280 & 112.55 & 99.05 & 97.92 \\
\hline & 2016 & 19010 & 105.51 & 92.84 & 91.79 \\
\hline & 2017 & 18040 & 100.12 & 88.11 & 87.11 \\
\hline & 2018 & 17719 & 98.34 & 86.54 & 85.56 \\
\hline & 2019 & 16300 & 90.47 & 79.61 & 78.70 \\
\hline \multirow{5}{*}{ Akyazı } & 2015 & 3456 & 19.18 & 16.88 & 16.69 \\
\hline & 2016 & 1500 & 8.33 & 7.33 & 7.24 \\
\hline & 2017 & 1000 & 5.55 & 4.88 & 4.83 \\
\hline & 2018 & 983 & 5.46 & 4.80 & 4.75 \\
\hline & 2019 & 1000 & 5.55 & 4.88 & 4.83 \\
\hline \multirow{5}{*}{ Arifiye } & 2015 & 444 & 2.46 & 2.17 & 2.14 \\
\hline & 2016 & 450 & 2.50 & 2.20 & 2.17 \\
\hline & 2017 & 50 & 0.28 & 0.24 & 0.24 \\
\hline & 2018 & 49 & 0.27 & 0.24 & 0.24 \\
\hline & 2019 & 40 & 0.22 & 0.20 & 0.19 \\
\hline \multirow{5}{*}{ Erenler } & 2015 & 1677 & 9.31 & 8.19 & 8.10 \\
\hline & 2016 & 2070 & 11.49 & 10.11 & 9.99 \\
\hline & 2017 & 2088 & 11.59 & 10.20 & 10.08 \\
\hline & 2018 & 1166 & 6.47 & 5.69 & 5.63 \\
\hline & 2019 & 1000 & 5.55 & 4.88 & 4.83 \\
\hline \multirow{5}{*}{ Ferizli } & 2015 & 2962 & 16.44 & 14.47 & 14.30 \\
\hline & 2016 & 3000 & 16.65 & 14.65 & 14.49 \\
\hline & 2017 & 2000 & 11.10 & 9.77 & 9.66 \\
\hline & 2018 & 1967 & 10.92 & 9.61 & 9.50 \\
\hline & 2019 & 1800 & 9.99 & 8.79 & 8.69 \\
\hline \multirow{5}{*}{ Geyve } & 2015 & 48300 & 268.07 & 235.90 & 233.22 \\
\hline & 2016 & 48101 & 266.96 & 234.93 & 232.26 \\
\hline & 2017 & 48640 & 269.95 & 237.56 & 234.86 \\
\hline & 2018 & 42199 & 234.20 & 206.10 & 203.76 \\
\hline & 2019 & 34500 & 191.48 & 168.50 & 166.58 \\
\hline \multirow{5}{*}{ Hendek } & 2015 & 2215 & 12.29 & 10.82 & 10.70 \\
\hline & 2016 & 1451 & 8.05 & 7.09 & 7.01 \\
\hline & 2017 & 1234 & 6.85 & 6.03 & 5.96 \\
\hline & 2018 & 1202 & 6.67 & 5.87 & 5.80 \\
\hline & 2019 & 1000 & 5.55 & 4.88 & 4.83 \\
\hline \multirow{5}{*}{ Karapürçek } & 2015 & 91 & 0.51 & 0.44 & 0.44 \\
\hline & 2016 & 69 & 0.38 & 0.34 & 0.33 \\
\hline & 2017 & 58 & 0.32 & 0.28 & 0.28 \\
\hline & 2018 & 51 & 0.28 & 0.25 & 0.25 \\
\hline & 2019 & 50 & 0.28 & 0.24 & 0.24 \\
\hline \multirow{5}{*}{ Karasu } & 2015 & 1230 & 6.83 & 6.01 & 5.94 \\
\hline & 2016 & 1217 & 6.75 & 5.94 & 5.88 \\
\hline & 2017 & 1089 & 6.04 & 5.32 & 5.26 \\
\hline & 2018 & 1057 & 5.87 & 5.16 & 5.10 \\
\hline & 2019 & 1038 & 5.76 & 5.07 & 5.01 \\
\hline \multirow{5}{*}{ Kaynarca } & 2015 & 36423 & 202.15 & 177.89 & 175.87 \\
\hline & 2016 & 24501 & 135.98 & 119.66 & 118.30 \\
\hline & 2017 & 22435 & 124.51 & 109.57 & 108.33 \\
\hline & 2018 & 22146 & 122.91 & 108.16 & 106.93 \\
\hline & 2019 & 22050 & 122.38 & 107.69 & 106.47 \\
\hline Kocaali & & 0 & 0 & 0 & 0 \\
\hline Sapanca & & 0 & 0 & 0 & 0 \\
\hline & 2015 & 985 & 5.47 & 4.81 & 4.76 \\
\hline & 2016 & 961 & 5.33 & 4.69 & 4.64 \\
\hline Serdivan & 2017 & 494 & 2.74 & 2.41 & 2.39 \\
\hline & 2018 & 345 & 1.91 & 1.68 & 1.67 \\
\hline & 2019 & 600 & 3.33 & 2.93 & 2.90 \\
\hline & 2015 & 2962 & 16.44 & 14.47 & 14.30 \\
\hline & 2016 & 3500 & 19.43 & 17.09 & 16.90 \\
\hline Söğütlü & 2017 & 2000 & 11.10 & 9.77 & 9.66 \\
\hline & 2018 & 1967 & 10.92 & 9.61 & 9.50 \\
\hline & 2019 & 3000 & 16.65 & 14.65 & 14.49 \\
\hline & 2015 & 34652 & 192.32 & 169.24 & 167.32 \\
\hline & 2016 & 20280 & 112.55 & 99.05 & 97.92 \\
\hline Taraklı & 2017 & 19010 & 105.51 & 92.84 & 91.79 \\
\hline & 2018 & 18040 & 100.12 & 88.11 & 87.11 \\
\hline & 2019 & 17719 & 98.34 & 86.54 & 85.56 \\
\hline & 2015 & 16300 & 90.47 & 79.61 & 78.70 \\
\hline & 2016 & 3456 & 19.18 & 16.88 & 16.69 \\
\hline Pamukova & 2017 & 1500 & 8.33 & 7.33 & 7.24 \\
\hline & 2018 & 1000 & 5.55 & 4.88 & 4.83 \\
\hline & 2019 & 983 & 5.46 & 4.80 & 4.75 \\
\hline
\end{tabular}


Table 4. Methane gas and energy potentials of wheat

\begin{tabular}{|c|c|c|c|}
\hline Locations & Year & Methane gas ( $\mathrm{m}^{3} /$ year) & Energy value (MJ/year) \\
\hline \multirow{5}{*}{ Adapazarı } & 2015 & 24.48 & 881.30 \\
\hline & 2016 & 22.95 & 826.11 \\
\hline & 2017 & 21.78 & 783.96 \\
\hline & 2018 & 21.39 & 770.01 \\
\hline & 2019 & 19.68 & 708.34 \\
\hline \multirow{5}{*}{ Akyazı } & 2015 & 4.17 & 150.19 \\
\hline & 2016 & 1.81 & 65.18 \\
\hline & 2017 & 1.21 & 43.46 \\
\hline & 2018 & 1.19 & 42.72 \\
\hline & 2019 & 1.21 & 43.46 \\
\hline \multirow{5}{*}{ Arifiye } & 2015 & 0.54 & 19.29 \\
\hline & 2016 & 0.54 & 19.56 \\
\hline & 2017 & 0.06 & 2.17 \\
\hline & 2018 & 0.06 & 2.13 \\
\hline & 2019 & 0.05 & 1.74 \\
\hline \multirow{5}{*}{ Erenler } & 2015 & 2.02 & 72.88 \\
\hline & 2016 & 2.50 & 89.95 \\
\hline & 2017 & 2.52 & 90.74 \\
\hline & 2018 & 1.41 & 50.67 \\
\hline & 2019 & 1.21 & 43.46 \\
\hline \multirow{5}{*}{ Ferizli } & 2015 & 3.58 & 128.72 \\
\hline & 2016 & 3.62 & 130.37 \\
\hline & 2017 & 2.41 & 86.91 \\
\hline & 2018 & 2.37 & 85.48 \\
\hline & 2019 & 2.17 & 78.22 \\
\hline \multirow{5}{*}{ Geyve } & 2015 & 58.30 & 2098.95 \\
\hline & 2016 & 58.06 & 2090.30 \\
\hline & 2017 & 58.71 & 2113.72 \\
\hline & 2018 & 50.94 & 1833.82 \\
\hline & 2019 & 41.65 & 1499.25 \\
\hline \multirow{5}{*}{ Hendek } & 2015 & 2.67 & 96.26 \\
\hline & 2016 & 1.75 & 63.06 \\
\hline & 2017 & 1.49 & 53.63 \\
\hline & 2018 & 1.45 & 52.23 \\
\hline & 2019 & 1.21 & 43.46 \\
\hline \multirow{5}{*}{ Karapürçek } & 2015 & 0.11 & 3.95 \\
\hline & 2016 & 0.08 & 3.00 \\
\hline & 2017 & 0.07 & 2.52 \\
\hline & 2018 & 0.06 & 2.22 \\
\hline & 2019 & 0.06 & 2.17 \\
\hline \multirow{5}{*}{ Karasu } & 2015 & 1.48 & 53.45 \\
\hline & 2016 & 1.47 & 52.89 \\
\hline & 2017 & 1.31 & 47.32 \\
\hline & 2018 & 1.28 & 45.93 \\
\hline & 2019 & 1.25 & 45.11 \\
\hline \multirow{5}{*}{ Kaynarca } & 2015 & 43.97 & 1582.82 \\
\hline & 2016 & 29.58 & 1064.73 \\
\hline & 2017 & 27.08 & 974.95 \\
\hline & 2018 & 26.73 & 962.39 \\
\hline & 2019 & 26.62 & 958.22 \\
\hline Kocaali & & 0 & 0 \\
\hline \multirow{2}{*}{ Sapanca } & & 0 & 0 \\
\hline & 2015 & 1.19 & 42.80 \\
\hline & 2016 & 1.16 & 41.76 \\
\hline Serdivan & 2017 & 0.60 & 21.47 \\
\hline & 2018 & 0.42 & 14.99 \\
\hline & 2019 & 0.72 & 26.07 \\
\hline & 2015 & 3.58 & 128.72 \\
\hline & 2016 & 4.22 & 152.10 \\
\hline Söğ̈ütlü & 2017 & 2.41 & 86.91 \\
\hline & 2018 & 2.37 & 85.48 \\
\hline & 2019 & 3.62 & 130.37 \\
\hline & 2015 & 41.83 & 1505.85 \\
\hline & 2016 & 30.63 & 1102.84 \\
\hline Taraklı & 2017 & 31.34 & 1128.13 \\
\hline & 2018 & 32.94 & 1185.93 \\
\hline & 2019 & 22.57 & 812.64 \\
\hline & 2015 & 17.83 & 641.72 \\
\hline & 2016 & 4.39 & 158.18 \\
\hline Pamukova & 2017 & 4.35 & 156.62 \\
\hline & 2018 & 4.25 & 152.92 \\
\hline & 2019 & 4.39 & 158.18 \\
\hline
\end{tabular}




\section{Conclusion and Recommendations}

Within the scope of the study, usable maize, wheat waste and energy potentials between 2015-2019 in Sakarya city center and its districts were determined. In line with the obtained results, it was determined that the waste and energy values that can be obtained from maize waste in Sakarya province are in Adapazarı district. The highest waste and energy values in Adapazarı district were determined as 25695.68 tons/year and 201197.15 MJ/year, respectively. The highest potential for waste and energy from wheat wastes was found in Geyve district as 269.95 tons/year and $2113.72 \mathrm{MJ} /$ year, respectively. As in the global dimension, transferring the energy potentials that can be obtained from the existing agricultural wastes in our country will contribute to the reduction of our energy dependency.

\section{References}

Afazeli H, Jafari A, Rafiee S, Nosrati M. 2014. An investigation of biogas production potential from livestock and slaughterhouse wastes. Renewable Sustain Energy Revolution, 34:380-6.

Aybek A, Üçok S, İspir MA, Bilgili ME. 2015. Türkiye'de kullanılabilir Hayvansal Gübre ve Tahıl Sap Atıklarının Biyogaz ve Enerji Potansiyelinin Belirlenerek Sayisal Haritalarının Oluşturulması. Tekirdağ Ziraat Fakültesi Dergisi, 12 (03), 111-120.

Bao W, Yang Y, Fu T, Xie GH. 2019. Estimation of livestock excrement and its biogas production potential in China. Journal of Cleaner Production, 229: 1158-1196.

Da Costa Gomez C. 2013. 1-biogas as an energy option: an overview. In: Wellinger A, Murphy J, Baxter D, (Eds), The Biogas Handbook. Woodhead Publishing Series in Energy. Woodhead Publishing, pp. 1-16.

Gao M, Wang D, Wang H, Wang X, Feng Y. 2019. Biogas potential, utilization and counter measures in agricultural provinces: A case study of biogas development in Henan Province, China. Renewable and Sustainable Energy Reviews, 99: 191-200.

Howell G, Bennett C, Materic D. 2019. A comparison of methods for early prediction of anaerobic biogas potential on biologically treated municipal solid waste. Journal of Environmental Management, 232: 887-894.
Khalil M, Berawi MA, Heryanto R, Rizalie A. 2019. Waste to energy technology: The potential of sustainable biogas production from animal waste in Indonesia. Renewable and Sustainable Energy Reviews, 105: 323-331.

Minguela JAV, Godoy FS. 2015. Digestion anerobia para la produccion de biogas. Tecnology, para el uso y Transform, Biomasa energetica, 317.

Momayez F, Karimi K, Horvath IS. 2018. Enhancing ethanol and methane production from rice straw by pretreatment with liquid waste from biogas plant. Energy Conversion and Management, 178: 290-298.

Monjurul Hasan ASM, Ammenberg J. 2019. Biogas potential from municipal and agricultural residual biomass for power generation in Hazaribagh, Bangladesh-A strategy to improve the energy system. Renewable energy, 29: 14-23.

Öztürk H, Başçetinçelik A. 2006. Energy exploitation of agricultural biomass potential in Turkey. Energy Exploration and Exploitation Dergisi, 24 (5), pp: 313-330.

Ramos-Suarez JL, Ritter A, Gonzalez JM, Perez AC. 2019. Biogas from animal manure: A sustainable energy opportunity in the Canary Islands. Renewable and Sustainable Energy Reviews, 104: 137-150.

Ruiz D, San Miguel G, Corona B, Gaitero A, Dominquez A. 2018. Environmental and economic analysis of power generation in a thermophilic biogas plant. Science of the Total Environment, 633: 1418-1428.

Sharma SK, Mishra IM, Sharma MP, Saini JS. 1988. Effect of particle size on biogas generation from biomass residues. Biomass, 17 (4): 251-263.

Tasova M, Naneli I. 2019. Bolu ve Tokat illerindeki buğday sap atıklarının enerji potansiyel değerlerinin karşılaștırmalı teorik analizi. International Journal of Life Sciences and Biotechnology, 2 (3): 136-144.

Ullah Khan I, Hafiz Dzarfan Othman M, Hashim H, Matsuura T, Ismail AF, Rezaei Dasht Arzhandi M. 2017. Biogas as a renewable energy fuel-a review of biogas upgrading, utilization and storage. Energy Convers Manage, 150: 27794.

Yentekakis IV, Goula G. 2017. Biogas management: advanced utilization for production of renewable energy and addedvalue chemicals. Front Environ Sci, 5.

Zareei S. 2018. Project scheduling for constructing biogas plants using critical path method. Renewable and Sustainable Energy Reviews, 756-7. 